\title{
Chemical Weed Control in Sugar Beet
}

\author{
Mahmoud S. Mahmoud and Fouad S. Soliman ${ }^{1}$
}

\begin{abstract}
A field experiment was carried out to evaluate the efficiency of some herbicide treatments (with and without handweeding) on sugar beet yield and yield components for two successive seasons (2010 and 2011) at Abbis farm, Faculty of Agriculture, Alexandria University, Alexandria, Egypt.
\end{abstract}

The treatments were Phenmedipham $6.5 \%+$ metametron $28 \%$ + ethofumesate $6.5 \%$ (crus) with a rate of $2 \mathrm{~kg} /$ feddan and $2.5 \mathrm{~kg} /$ feddan, Phenmedipham 5.54\% + desmedipham $4.34 \%$ + lenacil $2.5 \%$ + ethofumesate 6.93 (betanal maxxpro), acetochlor (harness), Phenmedipham $7.5 \%+$ desmedipham $1.5 \%+$ ethofumesate $11.5 \%$ (betasana trio), handweeding twice and Unweeded check, all previous herbicide treatments were repeated twice either with or without handweeding.

The dominant weed in both seasons was Beta vulgaris. The results in the first season showed that the best herbicide treatments which gave maximum weed reduction were handweeding twice, Acetochlor + handweeding, (Phenmedipham 6.5\% + metametron $28 \%+$ ethofumesate $6.5 \%) \quad 2.5 \mathrm{~kg} / \mathrm{fed}+$ handweeding , (Phenmedipham 6.5\% + metametron 28\% + ethofumesate 6.5\%) $2 \mathrm{~kg} /$ fed + handweeding, (Phenmedipham 7.5\% + desmedipham $1.5 \%+$ ethofumesate $11.5 \%)+$ handweeding and (Phenmedipham 5.54\% + desmedipham $4.34 \%+$ lenacil $2.5 \%+$ ethofumesate $6.93 \%$ ) + handweeding with no significant differences between them with a percentage of weed control $(98.7,97.7,96.7,96.2$, 95.8 and 93.7), respectively.

In the second season the best weed reduction was achieved by (Phenmedipham $6.5 \%$ + metametron $28 \%+$ ethofumesate $6.5 \%$ ) with a rate of $2.5 \mathrm{~kg} / \mathrm{fed}+$ handweeding with a percentage of control (97.3\%), handweeding twice $(96.8 \%)$, (Phenmedipham $6.5 \%+$ metametron $28 \%$ + ethofumesate $6.5 \%$ ) with a rate of $2 \mathrm{~kg} / \mathrm{fed}+$ handweeding $(\mathbf{9 6 . 1 \% )}$, Acetochlor + handweeding $\quad(\mathbf{9 5 . 8 \%})$, (Phenmedipham 7.5\%+ desmedipham $1.5 \%+$ ethofumesate $11.5 \%)+$ handweeding (93.6\%) and (Phenmedipham 5.54\% + desmedipham $4.34 \%+$ lenacil $2.5 \%+$ ethofumesate $6.93 \%)+$ handweeding $(91.6 \%)$ with no significant differences between them.

The highest yield in the first season was found in the case of (Phenmedipham $6.5 \%+$ metametron $28 \%+$ ethofumesate $6.5 \%$ ) $2.5 \mathrm{~kg} / \mathrm{fed}$ which gave $35.32 \mathrm{ton} / \mathrm{fed}$ followed by handweeding twice with a yield 31.82 ton/fed and (Phenmedipham 5.54\%+ desmedipham 4.34\%+ lenacil $2.5 \%+$ ethofumesate $6.93 \%$ ) with a yield 29.59 ton/fed with no significant differences between them in the second season the highest feddan production was reported in the case of (Phenmedipham $6.5 \%+$ metametron $28 \%+$ ethofumesate $6.5 \%) \quad 2.5 \mathrm{~kg} / \mathrm{fed}+$ handweeding and handweeding twice (34.23 and 33.18 ton/fed, respectively) with no significant difference between them.

The length and diameter of the root were not affected by the tested herbicides, also the percentage of sugar were not affected by all treatments, but in the first season, the highest sugar yield per feddan was found in the case of five treatments which were (Phenmedipham 6.5\%+ metametron $28 \%+$ ethofumesate $6.5 \%) 2.5 \mathrm{~kg} / \mathrm{fed}+$ handweeding, (Phenmedipham 5.54\% + desmedipham $4.34 \%+$ lenacil $2.5 \%+$ ethofumesate $6.93 \%$ ) + handweeding, handweeding twice, (Phenmedipham 6.5\%+ metametron $28 \%+$ ethofumesate $6.5 \%$ ) $2 \mathrm{~kg} / \mathrm{fed}+$ handweeding and (Phenmedipham 6.5\% + metametron $28 \%$ + ethofumesate $6.5 \%) 2.5 \mathrm{~kg} /$ fed with sugar yield (5.4, $4.98,4.73,4.64$ and 4.35 ton/fed, respectively with no significant differences between them while in the second season the four treatments that gave highest yield were (Phenmedipham 6.5\% + metametron 28\% + ethofumesate $6.5 \%) 2.5 \mathrm{~kg} / \mathrm{fed}+$ handweeding, handweeding twice, acetochlor + handweeding and (Phenmedipham $7.5 \%+$ desmedipham $1.5 \%$ + ethofumesate $11.5 \%$ ) + handweeding as they gave $(5.58,5.28,4.93$ and 4.64 ton/fed, respectively.

\section{INTRODUCTION}

Sugar beet is an important crop of arable rotations throughout the major growing regions of Egypt. It provides a valuable break crop returning organic matter to the soil and preventing the buildup of disease. The root of the beet has a sugar content of around $17 \%$.

Harvesters cut off the top leaves of the sugar beet which are used as animal feed for cattle and sheep or are ploughed back into the land as a natural fertilizer. The root is then cleaned to remove any soil attached to it before it is transported. Roots awaiting delivery to the factory are stored in protected storage to maintain the highest possible quality and sugar.

Weeds are known to cause crop yield losses, hamper harvest, reduce quality of the harvest product, and perhaps harbour insects and diseases that may harm the crop.

Yield losses are of the greatest concern and have been predicted using early season assessments of the weed population such as weed seedling density, relative time of emergence, weed pressure, and relative leaf area

\footnotetext{
${ }^{1}$ Department of Pesticide chemistry and Technology,

Faculty of Agriculture, Alexandria University

Received November 17, 2012, Accepted December 28, 2012.
} 
(Schweizer and May, 1993; Dieleman and Mortensen, 1998).

Sugar beet is a poor competitor with weeds in arable fields because it is slow growing early in the season and has a low canopy in its first year of a biennial life cycle (May, 2003). Sugar beet is not competitive with emerging weeds until it has at least 8 true leaves. The total potential losses from weeds would be between 50 and $100 \%$ of the potential crop yield (May, 2001). Weeds that emerge 8 weeks after sowing, and particularly after the sugar beet plants have eight or more leaves, are less likely to affect yield (Scott et al., 1979). The most competitive are annual weeds, mostly broadleaved species that emerge with, or shortly after, the crop, grow taller than the crop and produce dense shade. These weeds often grow to a height two to three times that of sugar beet by midsummer, sugar beet herbicides seldom have a wide enough weed control spectrum or sufficient residual activity to control all weeds, and tank mixes and sequences of different herbicides are commonly used in order to provide a broad spectrum of weed control (May and Wilson, 2006).

The most popular active ingredients are phenmedipham, metamitron, ethofumesate, desmedipham, triflusulfuron-methyl, lenacil, clopyralid and chloridazon (May, 2001). Herbicides are usually applied in tank mixes /Deveikyte, 2000; May, 2001; Wilson et al., 2005; Deveikyte and Seibutis, 2006).

Weeds damages in developing countries, by applying different methods of control, resulted in $10 \%$ decrease in performance of sugar beet. Without any control of weeds, damages fluctuate between 10 to $100 \%$ according to environmental conditions and genus of cultivated plant, economically (Kropff and Vanlour,
1993). Due to that chemical methods are among the most important ways of management in cultivating farms, using appropriate paths to improve the performance of herbicides must be considered.

Handweeding 10-20 weeks after planting sugar beet can keep the field clean until harvest time (Dawson, 1977).

The aim of this study is to find out the best treatment to control the weeds specially broad leaf weeds in sugar beet under Egyptian conditions.

\section{MATERIALS AND METHODS}

A field experiment was carried out in Abbis farm (Faculty of Agriculture farm), Alexandria, Egypt for two successive seasons 2010 and 2011) to estimate the effect of some herbicidal treatments on both broad and narrow leaf weeds.

This experiment was designed as a randomized complete block design with four replicates, tables (1 and 2) shows the herbicides application time and rate.

All tested herbicides were applied with a CP3 knapsack sprayer with red fan type nozzle. Handweeding twice and unweeded check were included in both season.

All cultural practices like fertilization and irrigation were applied as usual in sugar beet production.

Herbicides were evaluated after 45 days from application by collecting all weeds grown in $1 \mathrm{~m}^{2}$ randomly, weeds were sorted and weighted.

Percentage of weed reduction of each weed species as well as total of all weeds were calculated, also the effect of tested herbicides on yield, yield components (root length and diameter) were measured.

Table 1. Common name, trade name, concentration, formulation, and source of herbicidal treatments

\begin{tabular}{|c|c|c|c|c|c|}
\hline Herbicides & Common name & Trade name & Concentration (\%) & Formulation & source \\
\hline 1 & \multirow{4}{*}{$\begin{array}{l}\text { Phenmedipham } 6.5 \% \\
+ \text { metametron } 28 \%+ \\
\text { ethofumesate } 6.5 \%\end{array}$} & \multirow[t]{4}{*}{ Crus } & \multirow[t]{4}{*}{41} & \multirow[t]{4}{*}{$\mathrm{WG}$} & \multirow[t]{4}{*}{ Bridge trade } \\
\hline 2 & & & & & \\
\hline 3 & & & & & \\
\hline 4 & & & & & \\
\hline 5 & \multirow{2}{*}{$\begin{array}{l}\text { Phenmedipham } \\
5.54 \%+\text { desmedipham } \\
4.34 \%+\text { lenacil } 2.5 \%+ \\
\text { ethofumesate } 6.93 \%\end{array}$} & \multirow{2}{*}{$\begin{array}{l}\text { Betanal } \\
\text { maxxPro }\end{array}$} & \multirow[t]{2}{*}{19.31} & \multirow[t]{2}{*}{ OD } & \multirow{2}{*}{$\begin{array}{c}\text { Cairo } \\
\text { company }\end{array}$} \\
\hline 6 & & & & & \\
\hline 7 & \multirow[t]{2}{*}{ Acetochlor } & \multirow[t]{2}{*}{ Harness } & \multirow[t]{2}{*}{84} & \multirow[t]{2}{*}{$\mathrm{EC}$} & \multirow[t]{2}{*}{ Fine seeds } \\
\hline 8 & & & & & \\
\hline 9 & \multirow{2}{*}{ 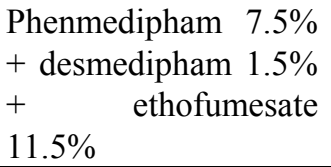 } & \multirow{2}{*}{$\begin{array}{c}\text { Betasana } \\
\text { trio }\end{array}$} & 20.5 & \multirow[t]{2}{*}{$\mathrm{SC}$} & \multirow[t]{2}{*}{ May trade } \\
\hline 10 & & & & & \\
\hline
\end{tabular}




\begin{tabular}{ll}
\hline 11 & Handweeding \\
\hline 12 & Unweeded check \\
\hline
\end{tabular}

Table 2. Treatments, Rate/feddan and Time of application

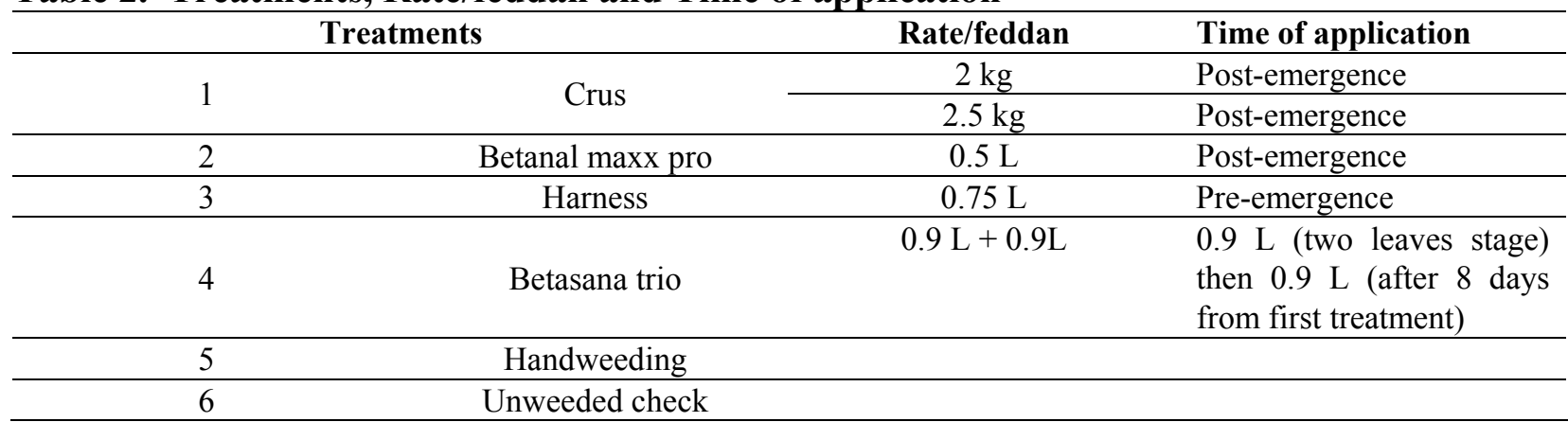

Percentage of sugar (Brix) was also measured by a hand refractometer (Atago N1, Brix 0 32\%).

Statistical analysis of data were carried out by assistat software version beta (Silva and Azevedo, 2009).

\section{RESULTS AND DISCUSSION}

Tables (3) and (4) shows that the dominant weed in the first season was Beta vulgaris with a a percentage of infection (51.6\%) followed by Medicago polymorpha (33.4\%), Phalaris minor (8.8\%), Marva parviflora $L$. (3.2\%) and Vicia monantha Retz. (3.1\%). In the second season the dominant weed was also Beta vulgaris with a percentage of infection (52\%) followed by Medicago polymorpha L. (32.4\%), Phalaris minor (9.6\%), Marva parviflora L.( $3.3 \%)$ and Vicia monantha Retz. (2.7\%). On the other hand, tables(3) and (4) also showed that the highest weed control in the first season was found in the case of handweeding twice, harness + handweeding, crus $2.5 \mathrm{~kg} / \mathrm{fed}+$ handweeding, crus $2 \mathrm{~kg} / \mathrm{fed}+$ handweeding, betasana trio + handweeding and betanal maxxpro + handweeding with no significant differences between them with a percentage of weed control (98.7, 97.7, 96.7, 96.2, 95.8 and 93.7), respectively, which indicated the role of handweeding in sugar beet weed control, the least percentage of control was observed in the case of betanal maxxpro ( $42.8 \%$ control). This is due to the ability of these treatments together with the handweeding to control the dominant weeds (Beta vulgaris and Medicago polymorpha).

The same results were obtained in the second season as the best treatments were crus $2.5 \mathrm{~kg} / \mathrm{fed}+$ handweeding with a percentage of control $(97.3 \%)$, handweeding twice $(96.8 \%)$, crus $2 \mathrm{~kg} / \mathrm{fed}+$ handweeding $(96.1 \%)$, harness + handweeding $(95.8 \%)$, betasana trio + handweeding $(93.6 \%)$ and betanal maxxpro+handweeding $(91.6 \%)$ with no significant differences between them, the least weed control was found in the case of Betanal maxxpro (51.1\%).
Concerning with narrow leaf weeds (Phlaris minor) in the first season, the best control was found in the case of harness thandweeding $(97.9 \%)$, followed by handweeding twice $(96.9 \%)$, the least control was in the case of betasana trio (46.1\%). In the second season, handweeding twice gave the best \%control (96.5\%) followed by crus $2 \mathrm{~kg} / \mathrm{fed}$ and crus $2.5 \mathrm{~kg} / \mathrm{fed}$ as they gave 90.7 and $90.6 \%$ control, respectively. The least control was shown by betanal maxxpro (57.5\%).

From table (5), it was noticed that the highest yield in the first season was found in the case of crus $2.5 \mathrm{~kg} / \mathrm{fed}$ (35.32 ton $/$ fed $)+$ handweeding followed by handweeding twice (31.82 ton/fed) and betanal maxxpro + handweeding (29.59 ton/fed) with no significant difference between the last two treatments, crus 2.5 $\mathrm{kg} /$ fed gave an acceptable yield (27.09 ton/fed) as there was no significant difference between it and Betanal maxxpro + handweeding, crus $2 \mathrm{~kg} / \mathrm{fed}+$ handweeding, betasana trio + handweeding and harness + handweeding $(29.59,29.15,28.98,26.96$ ton/fed, respectively), the least yield per feddan was found in the case of unweeded check (14.07 ton/fed) followed by crus $2 \mathrm{~kg}$ (19.45 ton/fed).

In the second season (table 6), the highest yield was found in the case of crus $2.5 \mathrm{~kg} / \mathrm{fed}+$ handweeding and handweeding twice (34.23 and 33.18 ton/fed, respectively) with no significant differences between them, also there were no significant differences between harness + handweeding, betasana trio + handweeding, crus $2 \mathrm{~kg} / \mathrm{fed}+$ handweeding and betanal maxxpro + handweeding ( 28.56, 27.51, 26.59 and 26 ton/fed, respectively), the least yield per feddan was found in the case of unweeded check (10.63 ton/fed), harness and crus $2 \mathrm{~kg} /$ fed gave a low yield 19.91 and 17.64 ton/fed, respectively with no significant differences between them.

These results agreed with Mohammad et al (2011), Who found that herbicides such as Metamitron and PDA 
(Phemedipham + Desmedipham + Autophpmisete $)$ and mixtures of Clopyralid and desmedipham and mixture of Desmedipham and trisulfuron methyl increased the performance of root yield up to 73.66, 70.73, 67.23 and 60.33 ton/hactar.

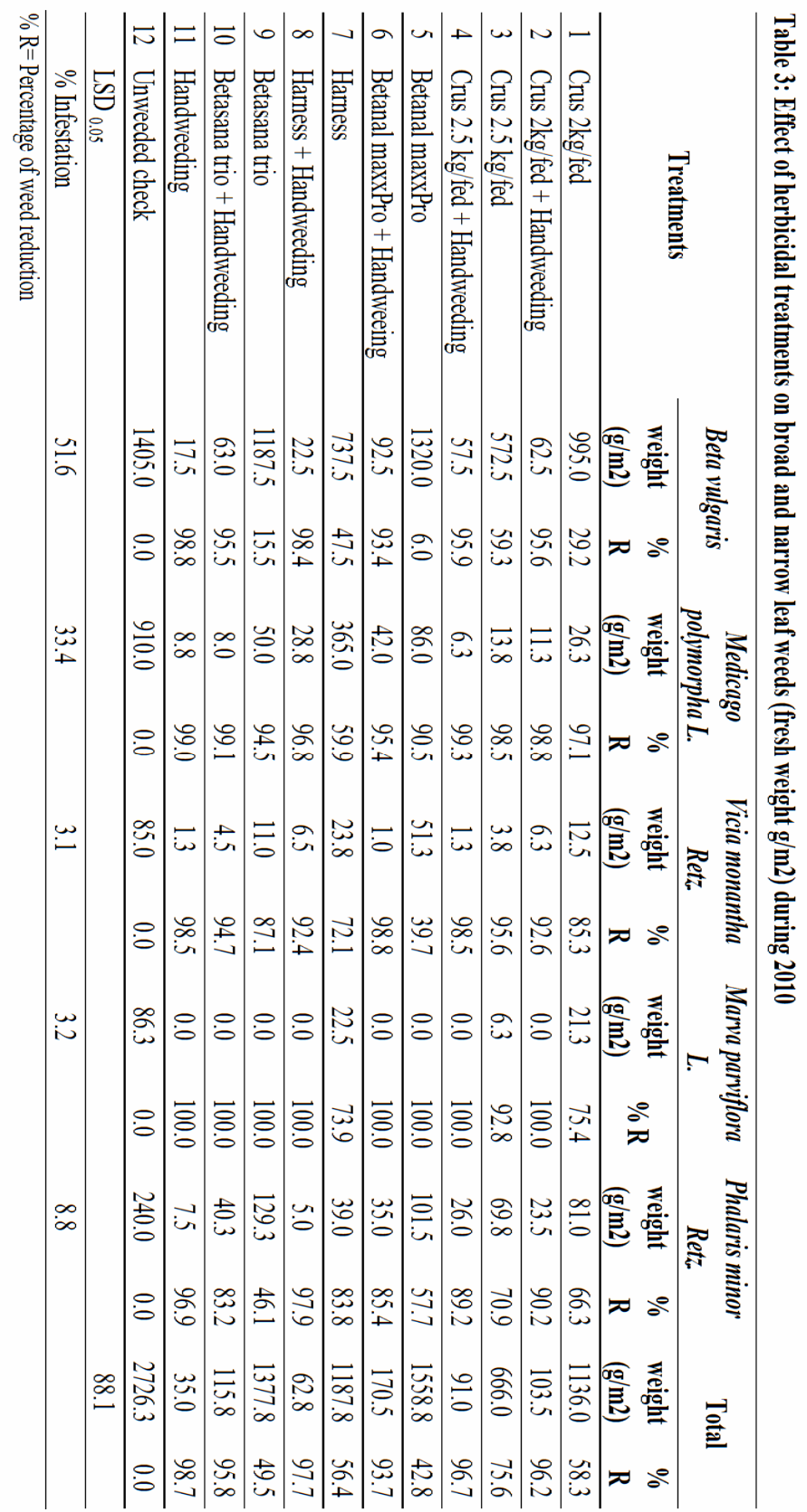




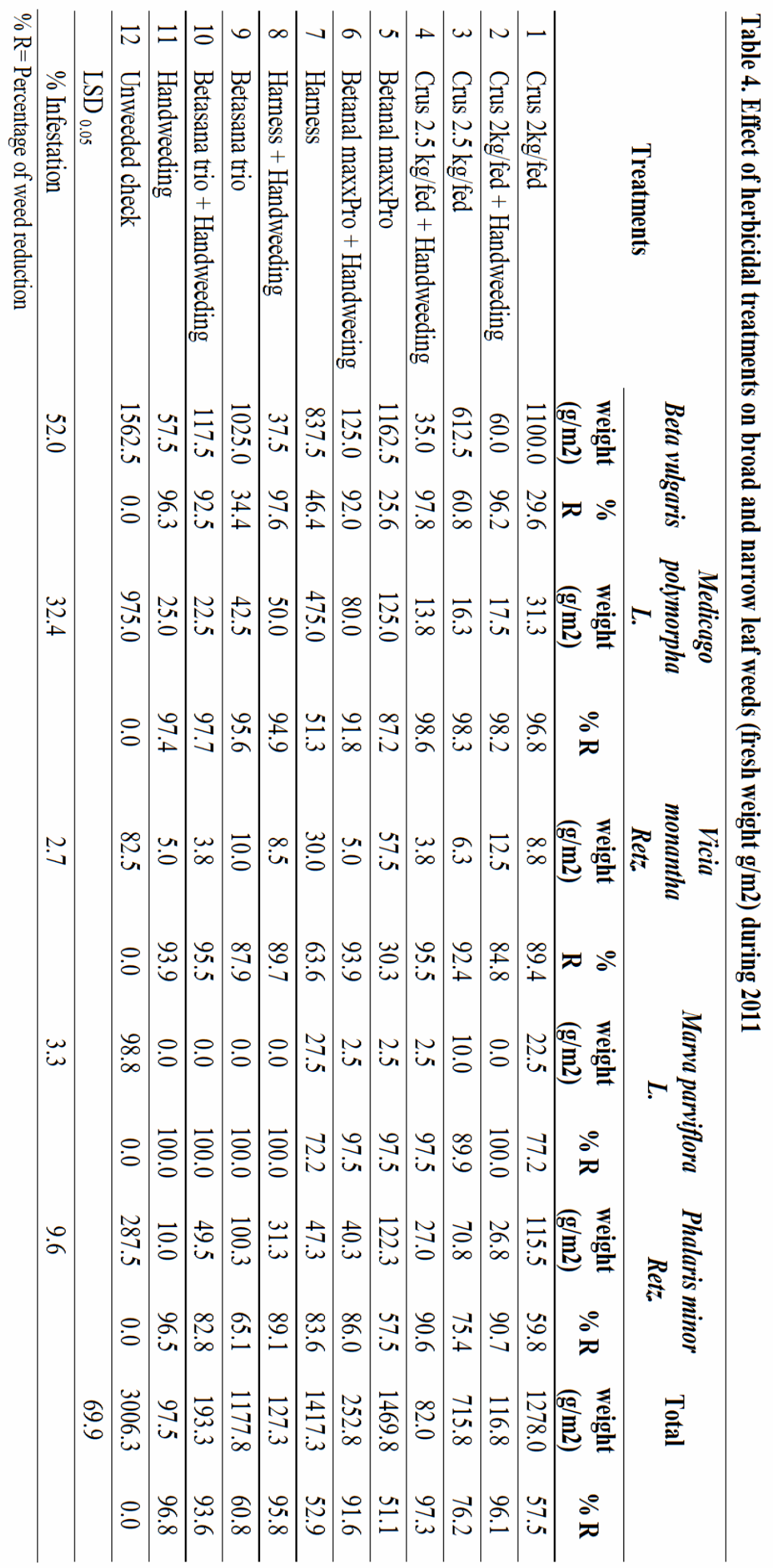




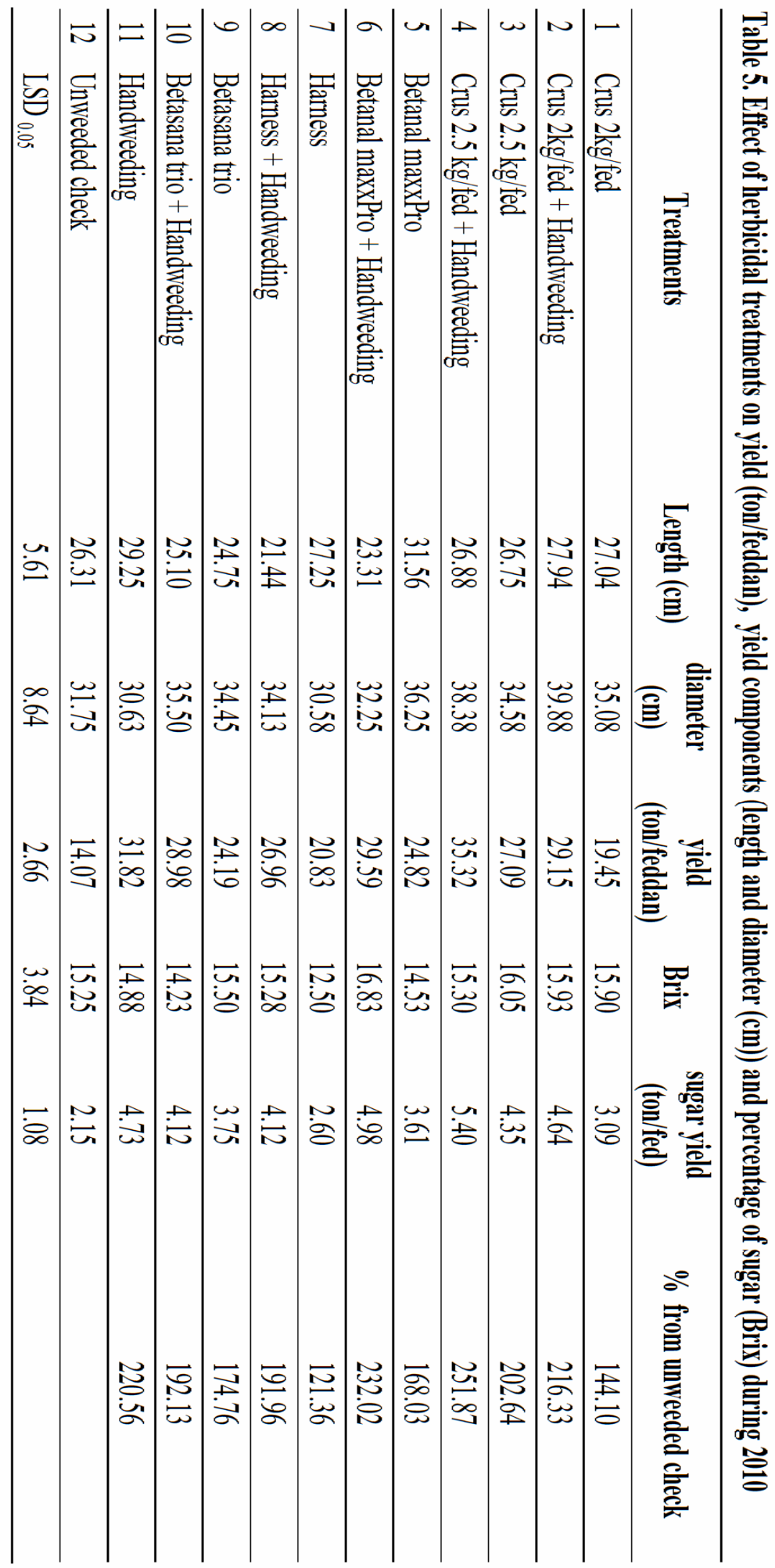




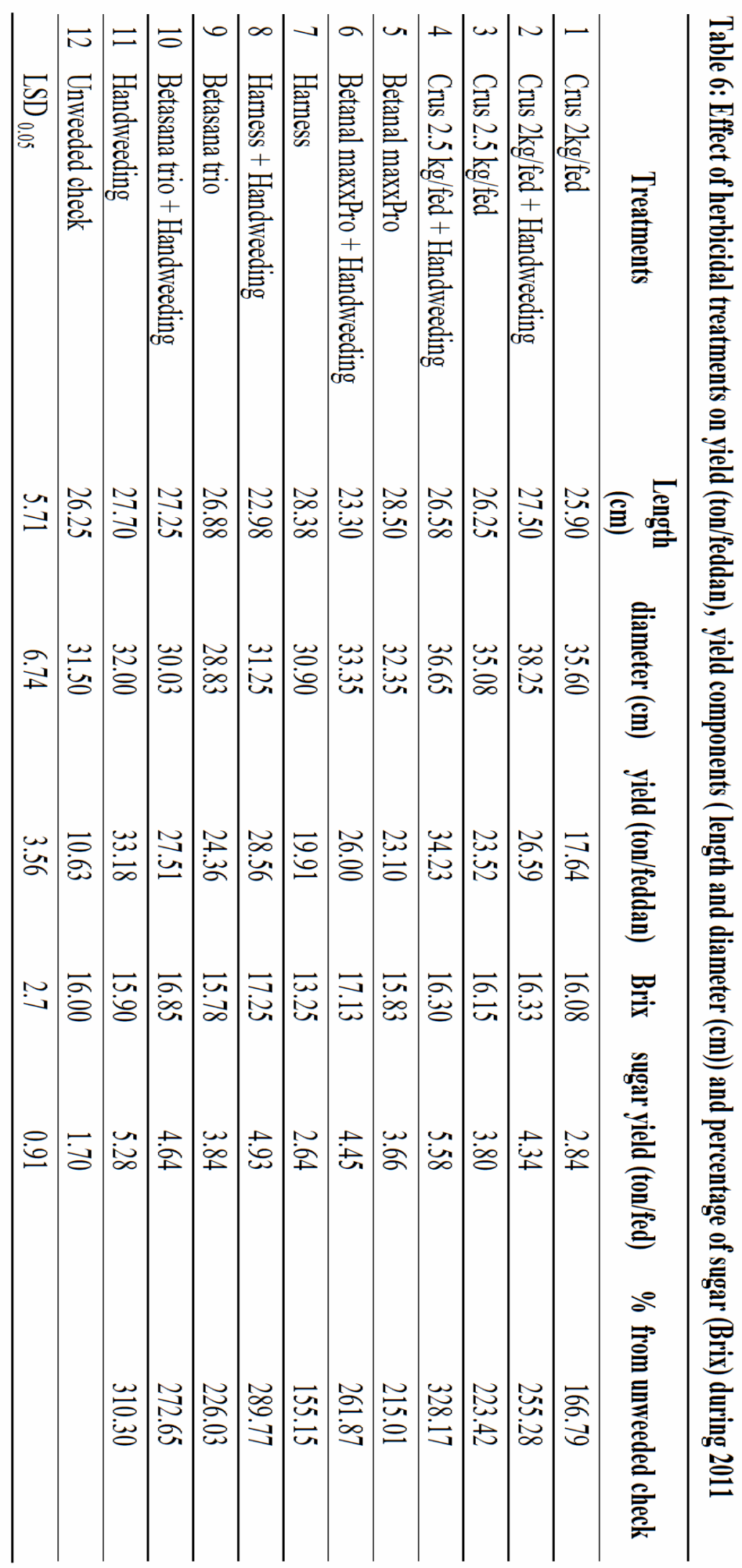


Conecrning with yield components, the highest length of root in the first season was found in the case of betanal maxxpro $(31.56 \mathrm{~cm})$ with no significant difference between all treatments except in the case of harness betanal maxxpro + handweeding and betasana trio with and without handweeding. In the second season, there was no significant difference between all treatments which indicated that the herbicide treatments don't affect the sugar beet root length.

Table(5) also showed that there was a very slight difference in root width of sugar beet in the first season as the highest width was found in the case of crus 2 $\mathrm{kg} / \mathrm{fed}+$ handweeding $(39.88 \mathrm{~cm})$ with no significant difference between all treatments except in the case of harness and handweeding twice (30.58 and 30.63 respectively) which was the least. Similarly in the second season (table 6) crus $2 \mathrm{~kg} /$ fed + handweeding recorded the highest width $(38.3 \mathrm{~cm})$ with a significant difference with unweeded check, harness + handweeding, harness, betasana trio + handweeding and betasana trio $(31.50,31.35,30.90,30.03$ and $28.83 \mathrm{~cm}$, respectively).

The data in table (5) showed that the percentage of sugar (brix) of the crop was not affected in the first season extremely by the treatments, the highest results was noticed in the case of betanal maxxpro + handweeding $(16.83 \%)$ with no significant difference between the rest of treatments except in the case of harness which was the least $(12.50 \%)$, there were no significant differences between either betanal maxxpro + handweeding and the rest of treatments or harness and the rest of treatments which was common between them.

In the second season, there were no significant differences between all treatments except in the case of harness least result $(13.35 \%)$ which was illustrated in table (6).

Betanal maxxpro + handweeding, betasana trio and handweeding were in between harness and the rest of treatments with no significant difference. These results indicates that the percentage of sugar was not affected by all tested herbicides.

This study agreed with Tevor et al (2006), who studied a post combination of desmedipham plus phenmedipham at $0.045+0.045 \mathrm{~kg}$ ai $/$ ha (desphen) or desmedipham plus phenmedipham plus ethofumesate ${ }^{3}$ (1:1: 1 ratio) (desphenetho) at $0.09 \mathrm{~kg}$ ai/ha plus triflusulfuron at $0.004 \mathrm{~kg}$ ai/ha plus clopyralid at 0.026 $\mathrm{kg}$ ai/ha plus $1.5 \%$ methylated seed oil received registration in 1998 and 2000 in North Dakota and
Michigan, respectively and found that herbicide rates are reduced by $80 \%$, compared to standard-split applications. Sugar beet populations and recoverable white sucrose per hectare did not differ among post herbicide treatments.

Abdallahi and Ghadiri (2004) found that maximum reduction in weed biomass was observed with desmedipham plus phenmedipham plus ethofumesate at $0.23+0.23+0.23 \mathrm{~kg}$ ai $/ \mathrm{ha}$ and desmedipham plus phenmedipham plus propaquizafop at $0.46+0.46+0.1$ $\mathrm{kg}$ ai/ha. Efficacy of grass herbicides was reduced when they were combined with pyrazon. Highest crop injury in both years was observed with desmedipham plus phenmedipham plus ethofumesate at $0.23+0.23+0.23$ $\mathrm{kg} / \mathrm{ha}$. Highest and lowest root yields in both years were produced in weed-free and weedy check plots, respectively. All herbicide treatments produced lower sugar beet yields than the hand-weeded check. Of the herbicide treatments evaluated, the highest sugar beet yields were with desmedipham plus phenmedipham plus propaquizafop at $0.46+0.46+0.1 \mathrm{~kg} / \mathrm{ha}$ in 2001 and with desmedipham plus phenmedipham plus ethofumesate at $0.23+0.23+0.23 \mathrm{~kg} / \mathrm{ha}$ in 2000 . Sucrose content and other sugar beet characteristics were not affected by the herbicide treatments

Also, it was found that planting pattern had proper effect on weeds biomass that best results were obtained in twin row planting $60 \mathrm{~cm}$. Also, mechanical control at 4 leaves stage of sugar beet had the best effect on weeds density and biomass. metamitron plus combination of phenmedipham + desmedipham + ethofumesat had also the best effect on weeds density and biomass. (Zargar and Rostami, 2011).

The results in table (5) indicated that sugar yield per feddan in the first season increased in five treatments (crus $2.5 \mathrm{~kg} / \mathrm{fed}+$ handweeding, betanal maxxpro + handweeding, Handweeding twice, crus $2 \mathrm{~kg} / \mathrm{fed}+$ handweeding and crus $2.5 \mathrm{~kg} / \mathrm{fed}$ ) as they gave $5.4,4.98$, $4.73,4.64$ and 4.35 ton/fed, respectively with percentage from unweeded check 251.87, 232.02, $220.56,216.33$ and $202.64 \%$, respectively, also the results in this table showed that there was no significant difference between betasana trio + handweeding and harness + handweeding as they both gave 4.12 ton/fed.

The least sugar yield was found in the case of unweeded check (2.15 ton/fed), harness (2.6 ton/fed) with percentage from unweeded check (121.36\%) and crus $2 \mathrm{~kg} / \mathrm{fed}$ (3.09 ton/fed) with percentage from unweeded check $(144.1 \%)$ with no significant differences between them. 
In the second season as shown in table (6), the highest increment in sugar yield per feddan was reported in four treatments crus $2.5 \mathrm{~kg} / \mathrm{fed}+$ handweeding, handweeding twice, harness + handweeding and betasana trio + handweeding as they gave $(5.58,5.28,4.93$ and 4.64 ton/fed, respectively), with percentage from unweeded check 328.17, 310.3, 289.77 and $272.65 \%$, respectively with no significant differences between them, also there was no significant diffence between harness + handweeding (4.93 ton/fed), betasana trio + handweeding ( 4.64 ton/fed) and betanal maxxpro + handweeding (4.45 ton/fed) with percentage from unweeded check 289.77, 272.65 and 261.87\%, respectively.

The unweeded check gave the least sugar yield per feddan (1.7 ton/fed), also harness and crus $2 \mathrm{~kg} / \mathrm{fed}$ gave lower sugar yield than the rest of treatments $(2.64$ and 2.84 ton/fed, respectively) with percentage from unweeded check 155.15 and $166.79 \%$, respectively.

The previous results in both seasons indicated the important role of herbicide treatments with the aid of handweeding in increasing the sugar beet yield as well as sugar yield in sugar beet crop.

\section{REFERENCES}

Abdullahi, F. and H. Ghadiri, 2004. Effect of Separate and Combined Applications of Herbicides on Weed Control and Yield of Sugar Beet. Weed technology, 18 (4): 968976.

Dawson, J.H., 1977. Competition of late emerging weeds with sugar beet Weed Science, 25: 165-169

Deveikyte I., 2000. Biological effectiveness the mixture of herbicides for sugar beet. Development of environmentally friendly plant protection in the Baltic region., p. 28-30. c.f. Deveikyte, I. and V. Seibutis, 2008. The influence of post emergence combinayions on broadleaved weeds in sugar beet. Zemdirbyste-Agriculture, 53 (3): 43-49.

Deveikyte I. and V. Seibutis, 2006. Broadleaf weeds and sugar beet response to phenmedipham, desmedipham, ethofumesate and Triflusulfuron-methyl. Agronomy Research. 4:159-162.

Dieleman J. A. and D.A. Mortensen, 1998. Influence of Weed Biology and Ecology on Development of Reduced Dose Strategies for Integrated Weed Management Systems // Integrated weed and soil management / eds. J. L. Hatfield, D. D. Buhler, B. A. Stewart. - ANN Arbor Press, p. 333362 c.f. Deveikyte, I. and V. Seibutis, 2008. The influence of post emergence combinayions on broad-leaved weeds in sugar beet. Zemdirbyste-Agriculture, 53 (3): 43-49.

Kropff, M.J and H.H. Vanlour, 1993. Crop weeds Interactions. Cab. International Walling ford, UK, pp: 273.

May M. 2001, Crop protection in sugar beet. Pesticide Outlook.12(5): 188-191. . c.f. Deveikyte, I. and V. Seibutis, 2008. The influence of post emergence combinayions on broad-leaved weeds in sugar beet. Zemdirbyste-Agriculture, 53 (3): 43-49.

May M. J., 2003. Economic consequences for UK farmers of growing GM herbicide tolerant sugar beet. Annals of Applied Biology. 142: 41-48.

May M. J. and R.G. Wilson, 2006. Weeds and weed control // Sugar beet / eds. A. P. Drycott. - Blackwell Publishing Ltd, p. 359-386.

Mohammad majidi, G. heidari and K. Mohammadi, 2011. Management of broad leaved weeds by combination of herbicides in sugar beet production. Advances in environmental biology , 5 (10): 3302-3306.

Schweizer E. E. and M.J. May, 1993. Weeds and weed control. The sugar beet crop/ed.D. A. Cooke, R. K. Scott. - Chapman and Hall, p. 485-519.

Scott R.K., S.J. Wilcockson and F.R. Moisey, 1979. The effects of time of weed removal on growth and yield of sugar beet. Journal of Agricultural Science. 93, p. 693709. c.f. Deveikyte, I. and V. Seibutis, 2008. The influence of post emergence combinayions on broadleaved weeds in sugar beet. Zemdirbyste-Agriculture, 53 (3): 43-49.

Silva, F. de A. S. e. and C. A. V. de. Azevedo. 2009. Principal components Analysis in the Software Assistat-Statistical Attendance. In: World congress on computer in agriculture, 7, Reno-NV-USA: American Society of Agricultural and Biological Engineers, 2006: 393-396.

Trevor, M.D., K.A. Renner and A. N. Kravchenko, 2006. Effect of Herbicides on Weed Control and Sugarbeet (Beta vulgaris) Yield and Quality. Weed Technology, 20 (1): $150-156$.

Wilson R. G., J.A. Smith and C.D. Yonts, 2005. Repeated reduced rates of broadleaf herbicides combination with methylated seed oil for post emergence weed control in sugar beet (Beta vulgaris). Weed Technology. 19(4): 855860.

Zargar, M. and R. Rostami, 2011. Response of Broad Leaf Weeds to Chemical and Non-Chemical Management Methods in Sugar Beet Field. American-Eurasian J. Agric. \& Environ. Sci., 11 (3): 392-397. 


\section{प]

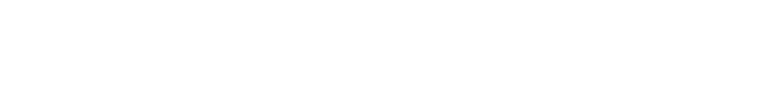

]ـمودشحاة [لمود، فؤادشعبلنسليملن

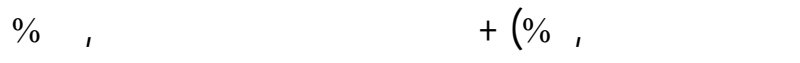
بدون فرق معنوى بينهم.

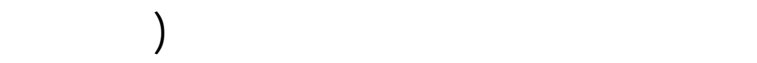

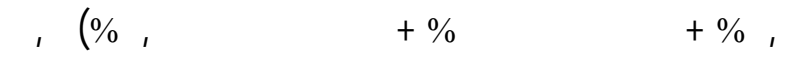

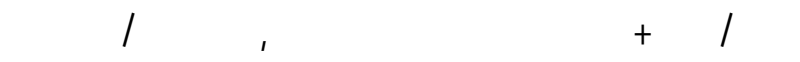

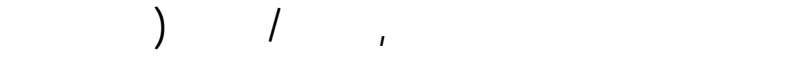

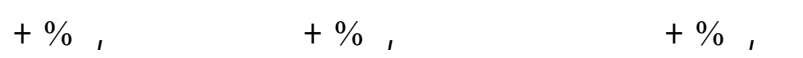

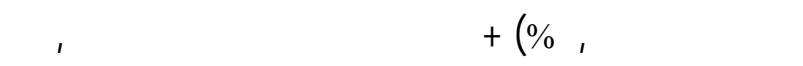

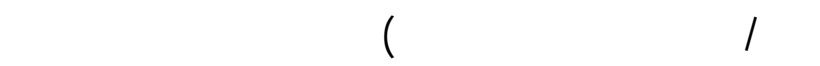

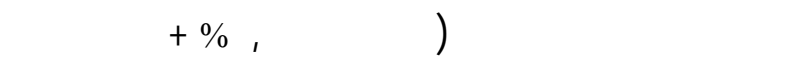

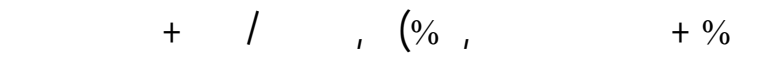

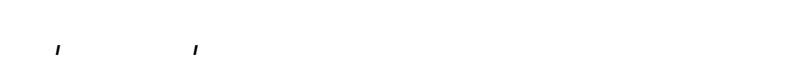
طن لفدل على التوالـ بدون فرق معنوى بينهم.

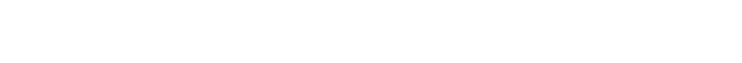

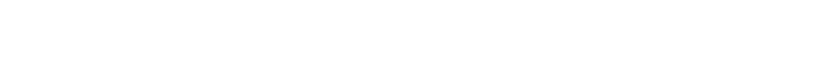

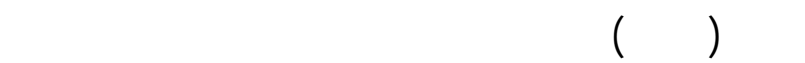

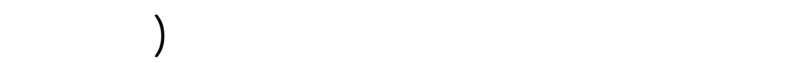

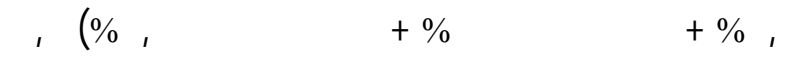

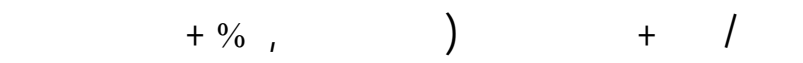

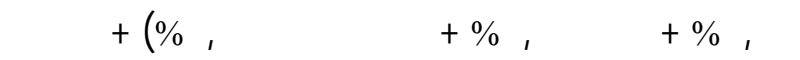

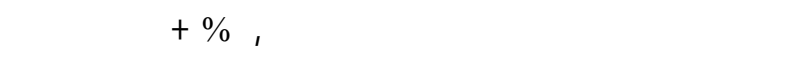

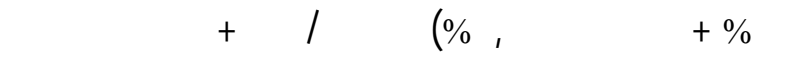

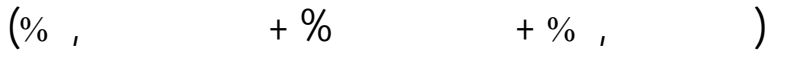

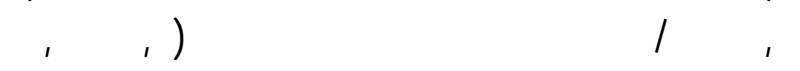

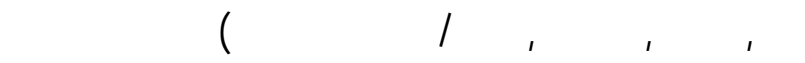

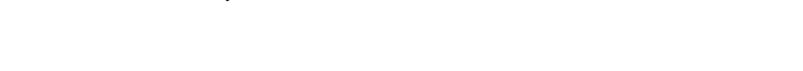

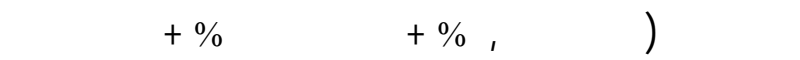

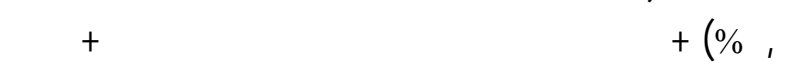

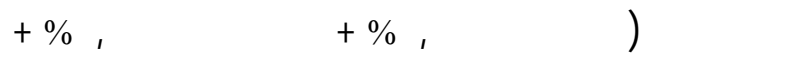

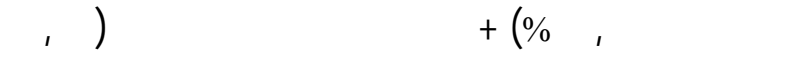

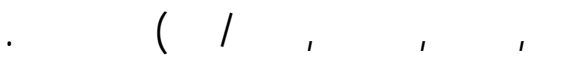

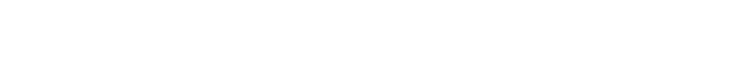

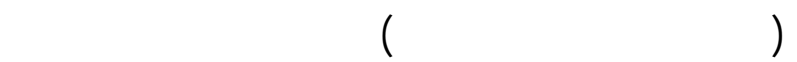

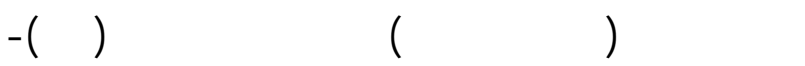
جلمة الإسكنرية - الإسكندرة - لـورية مصر العربية.

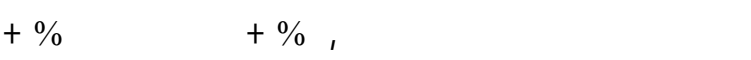

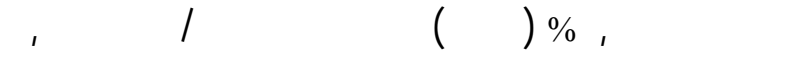

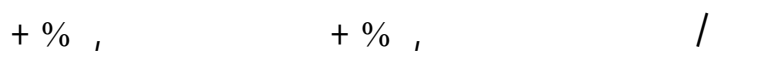

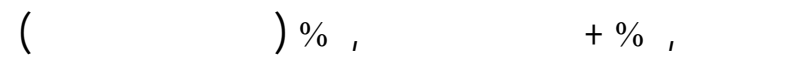

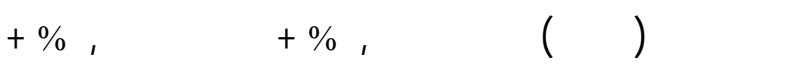

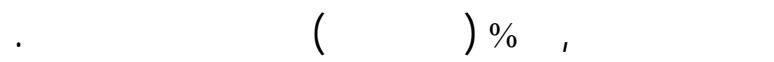

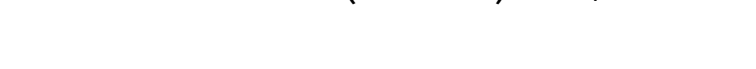

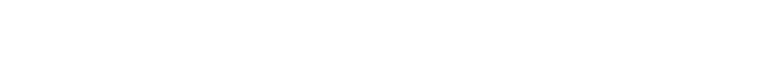

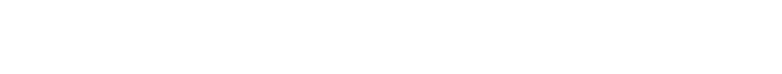

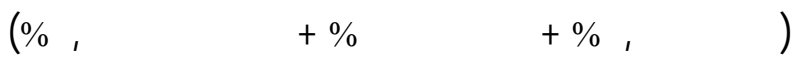

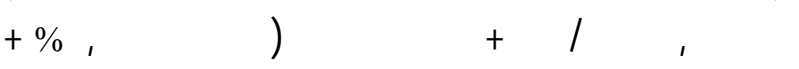

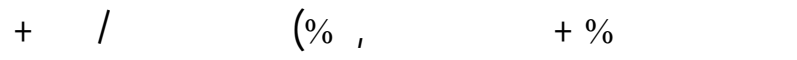
كزق ي دوى، (فينمي حيفل

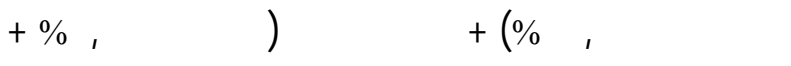

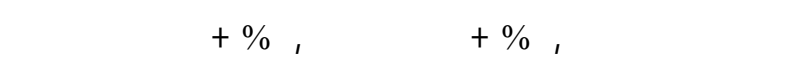

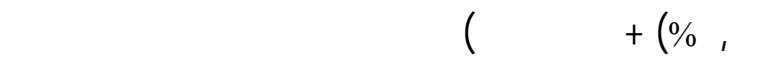
مكفح ـ ـ (

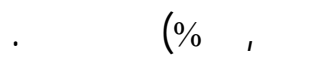

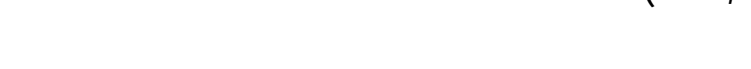

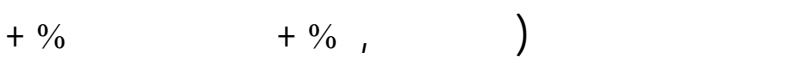

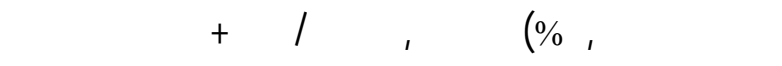

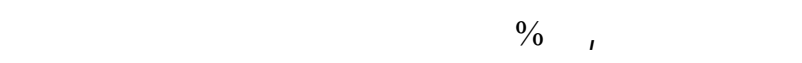

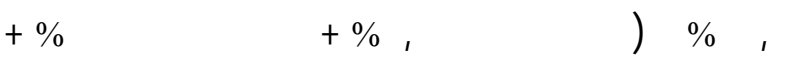

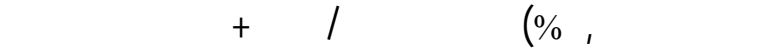

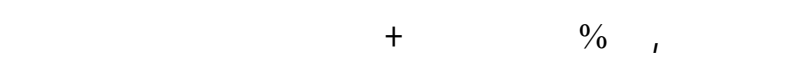

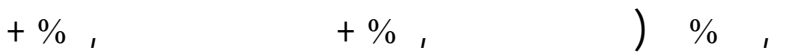

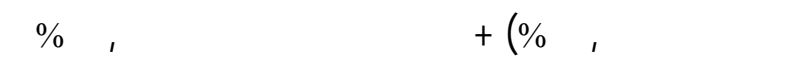

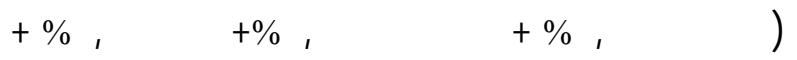

